\title{
Effectiveness of Community Nurse Home Visits in Improvement of Infant Mortality and Health from the Perspectives of Community Health Nurses in Jordan
}

\author{
Ürdün'de Toplum Sağlığı Hemşireliği Perspektifinden Bebek Ölümleri ve Sağlıkta İyileştirme için Toplum Hemşire \\ Ev Ziyaretlerinin Etkinliği
}

Mariam Kawafha

Irbid National University, Jordan

\begin{abstract}
Objective: Pregnant mothers in the rural areas of Jordan are known to face multiple health risks for their infants. Currently, individuals tend to face barriers to access clinic-based services. Evidence indicates that majority of infant deaths in Jordan occur due to this reason, which can be prevented through provision and promotion of infant care practices through home visits. This study aims to assess the effectiveness of community nurse home visits from the perspectives of community health nurses to improve infant mortality rates within the rural areas of Jordan.

Methods: A hundred community health nurses were recruited from the rural areas of Jordan (the response rate was $100 \%$ ). Quantitative method along with descriptive techniques and Pearson correlation test is utilized for analyzing responses obtained from participants.

Results: The majority of community health nurses revealed that the inclusion of community nursing is beneficial for healthcare sector. Approximately, $49 \%$ of experienced community nurses revealed that infant mortality rates can be easily controlled through home visits. A significant relationship exists between the increase in community nurse home visits and declined rates of infant mortality.

Conclusion: Home visits by community nurses play a crucial role in improving infant mortality rates and health. Various interventions are required to inspect the most efficient strategy to promote infant care practices and reach families living in the rural areas of Jordan. The community health visiting profession needs to embrace the national guidelines to offer safer information to mothers during pregnancy and throughout the initial year of a child's life.
\end{abstract}

Key Words: Nurses, community health, mortality, infant, house calls, treatment outcome

\section{ÖZET}

Amaç: Ürdün'ün kırsal bölgelerinde yaşayan hamile annelerin, bebekleri için birden fazla sağlık riski ile karşı karşıya geldikleri bilinmektedir. Güncel olarak, bireyler klinik tabanlı hizmetlere erişirken engellerle karşılaşmak eğilimindedir. Kanıtlar, Ürdün'deki bebek ölümlerinin çoğunluğunun bu nedene bağlı olduğunu ve ev ziyaretleri yoluyla bebek bakım uygulamalarının sağlanması ve desteklenmesi yoluyla önlenebileceğini de işaret etmektedir. Bu çalışma, toplum sağlığı hemşirelik perspektiflerinden bakarak toplum hemşireliği ev ziyaretleri etkinliğini Ürdün'ün kırsal bölgelerindeki bebek ölüm oranlarını iyileştirmek bağlamında ölçmeyi amaçlamaktadır.

Gereç ve Yöntem: Ürdün'ün kırsal alanlardan 100 toplum sağ|ığı hemşiresi dahil edildi (cevap oranı \% 100 idi). Katılımcılardan elde edilen yanıtların analizi için tanımlayıcı teknikler ve Pearson korelasyon testi gibi nicel yöntemler kullanıldı. Bulgular: Toplum sağlığı hemşirelerin çoğunluğu, toplum hemşireliğinin sisteme dahil edilmesinin sağlık sektörü için yararlı olduğunu ortaya koymuştur. Deneyimli toplum hemşirelerinin yaklaşık \% 49'u bebek ölüm oranlarının ev ziyaretleri yoluyla kolaylıkla kontrol edilebilir olduğunu tecrübe etmişlerdir. Toplum hemşireliği ev ziyaretlerinde artış ile bebek ölümleri oranındaki azalma arasında anlamlı bir ilişki bulunmaktadır.

Sonuç: Toplum hemşireleri tarafından uygulanan ev ziyaretleri, bebek ölüm oranlarını azaltmada ve sağlığın geliştirilmesinde önemli bir rol oynamaktadır. Bebek bakım hizmetleri ve Ürdün'ün kırsal bölgelerinde yaşayan ailelere ulaşmayı desteklemek ve en etkili stratejiyi incelemek için çeşitli müdahaleler gerekmektedir. Toplum sağ|ı̆̆ı ziyaret mesleğinin gebelik sırasında ve bebeklerinin ilk yılı süresince annelere güvenli bilgi sunuması için ulusal kılavuzları benimsemesi gerekmektedir.

Anahtar Sözcükler: Hemşireler, toplum sağlığı, ölüm, bebek, ev aramaları, tedavi sonuçları

Geliş Tarihi: 18.12.2015

Kabul Tarihi: 19.04.2016 


\section{INTRODUCTION}

The economic boom of the 1970s contributed towards home visiting becoming a part of Jordan's landscape. The Ministry of Health, through maternal child health clinics that had spread over all Jordan, was responsible for home visits in addition to a few private home visit clinics, mainly located in Amman. The home visitors were sent to the homes of the poor population in order to act as an exemplar for assisting them to opt for better life and health standards $(1,2)$. Currently, home visits for early childhood is an extensively disseminated approach to optimize the development and health of an infant. On estimate, $400,000-500,000$ families were annually served by the programs of home visits leading up to 2010 , along with a succeeding national investment of about 1.5 billion US dollars extended the reach (3-5). Whereas the model varies in content and focus, the programs of home visits are known to share a main goal to support child development and develop parenting skills (6). Increasing evidence is known to link positive early experiences to vigorous development of the brain, as well as revealing the risky physiological consequences of insufficient nurturing $(7,8)$.

The flourishing engagement in home visits of "at risk-families" offers the prospect to either mitigate or prevent the unfavorable experiences in childhood, along with promoting normative development. Evidence for the efficacy of home visits has demonstrated favorable effects for preventing unfavorable infant outcomes for instance, mortality or delayed development (9-12). However, as soon as it is taken to the scale in a certain community, the health visit programs reduced efficacy (13). The majority of the families enrolled in the home visit programs are known to receive few home visits as prescribed and nearly fifty percent of the population exit the program before the child turns twelve months old $(14,15)$. Though new studies indicated that the participation impact may not follow a simple dose-response association, participation levels can therefore influence the outcomes of the programs (16). For instance, a high frequency pertaining to home visits is linked with increased favorable gestational age at birth and positive parenting behaviors $(17,18)$. Improving participation in home visits by means of retention and engagement might assist to generate substantive and reliable program effects.

The rates of infant mortality are founded on the registered deaths, which were estimated to be $6 / 1,000$, live births (19). According to Dababneh et al., 20,000 deaths are registered per year in Jordan(20). Despite the substantial decrease in the rates of infant mortality over previous years, this gap in infant mortality rates in the rural areas of Jordan are considerably high. Moreover, the "full term infants" born to "low income families" in rural areas are known to suffer from higher rates of developmental problems and morbidity (21). Hence, a modern delivery approach related to healthcare that identifies the environmental, as well as social aspects affecting health of an infant are immediately required especially for the rural areas of Jordan. Nagy also emphasized studying the importance of the infant stage in the context of psychology, reflecting the importance of various social responses and preferences required(22). Globally, an extensively utilized primary health approach is to incorporate trained community workers as an element of a team of nurses. However, the community personnel in Jordan have not been widely utilized to promote the health of an infant.

Clinical settings are not considered to be an ideal venue to discuss sensitive concerns for instance, parenting behavior and maternal mental health such as breastfeeding or co-sleeping concerns. Studies indicate that parents consider clinics to be an inappropriate environment for private discussion with community workers or health visitors, while the home environment is thought to be the most favorable for developing relationships $(23,24)$. Home visiting is often valued by health visitors and clients as part of a widespread health visiting service, and is central to the delivering of advice pertaining to health promotion to families (25-27). According to Plews, people are more receptive to recommendation and advice attained during home visits(28). Such visits offer time to discuss concerns and privacy along with offering suitable conditions for parents to disclose sensitive concerns such as co-sleeping behaviors or domestic violence that healthcare providers may perceive to be contrary or alternative to guidelines (29).
According to the Department of Health, a widespread offer of a new birth visit and antenatal contact at ten-fourteen days summarized in the Healthy Child Programs offers an opportunity for the home visits to undertake an inclusive assessment of health needs, and to discuss advice related to health promotion around safe-infant sleeping practices(30). On the other hand, Donetto and Maben stated that parents are known to value contact with the services of health visiting outside of the home(31). The prospect to attend clinics for child health diminishes their sense of social seclusion, as well as permitting them to form parental autonomy. By means of dynamic assessment of health needs, as well as skillful communication, community health visitors can examine which family would advantage follow-up appointments or targeted home visits to discuss complicated issues for instance, infant mortality. Moreover, rural areas need excessive concentration when compared to urban areas in the observation of infant mortality rates.

The aim of the study is to examine the effectiveness of community-based enrichment of home visits to improve infant mortality and health. It needs to be predominantly implemented within the high-risk communities of the rural areas of Jordan, which is known to have poor infant health outcomes and low retention concerning the programs of home visits.

Numerous community-based resources are required to leverage community home visits for the purpose of addressing genuine family requirements, while supporting home visit programs and community acceptance. Efforts are needed to reach all new mothers in the rural areas (or communities) of Jordan that are eligible for home visit services. These aspects can drastically assist in improving the current approaches practiced in Jordan.

\section{MATERIALS and METHODS}

\section{Research Design}

A cross-sectional quantitative research design was used to reveal the diverse range of specified outcomes related to the effectiveness of home visits by community health nurses. Cross-sectional approach is used to revea advanced outcomes related to the research project. Different methods of carrying out research are documented in the literature, and among these methods, one of the most effective is quantitative research.

Quantitative research methodology is a preferred choice by the majority of researchers because it allows an individual to compare different variables and to measure the impact of one variable against others (32). Surveys are also useful when the large groups are involved in a research with the requirement of standardization. There are two main constituents of a survey; questions and responses.

\section{Data Collection}

A survey questionnaire was used as a data collection procedure. Survey is a technique which comprises a set of items in the form of judgments or arguments applicable to a person's reaction. The survey questionnaires include close-ended questions, which are quick and easy for the target audience to attempt to answer. The items of questionnaires comprise of demographic information related to the participants experience in home health, training, and level of professional satisfaction. In total, seven survey questions were developed to examine if the mortality rates of infants can be improved through home visiting by community health nurses. The majority of the queries were related to training in-home healthcare, a supportive social network and education related to new guidelines that aid to improve the infant mortality rate. These survey questions helped to determine how training and education could improve the infant mortality rate. The infant mortality rate was measured through secondary studies and compared in the discussion. This study adds knowledge to the existing body of literature that education and training is important to improve the community health nurse awareness about home visits, which ultimately lead to the improvement in infant mortality rates. 
Study Sample Settings and Population

This research study has been conducted in the rural areas of Jordan. Community health nurses have been selected from different rural areas of Jordan in order to examine the effectiveness of community nurse home visits in improving rates of child mortality and health. In total, a random sample of 100 community health nurses has been surveyed. Random sampling method or probability sampling is employed so that each sample of the same size may have an equal probability of being selected. That is, each element in the population has an equal chance of being selected.

\section{Data Analysis}

The quantitative research data has been analyzed through two different computer software, including Microsoft Excel and SPSS (version 20). A statistical technique is applied to the data collected from the survey in order to obtain precise, reliable, valid, and applicable results. Differential statistical tests, including descriptive test, frequency and Pearson correlation test were performed in order to achieve relative outcomes within the research study.

\section{Ethical Consideration}

Informed consent was provided by the community health nurses in order that the participant's responses could be analyzed in the findings of the research. The participants were required to complete consent forms beforehand and return them to the researchers.

\section{RESULTS}

The investigation was based on finding the effectiveness of community nurse home visits from the perspectives of community health nurses in order to reduce infant mortality rates within rural areas of Jordan. This section demonstrates the demographic findings of the respondents. The questionnaire was sent to 100 community health nurses working in rural Jordan. All 100 respondents replied to the survey, yielding a response rate of 100 percent.

Table 1, in the Appendix, demonstrates the gender of the survey respondents. In this research, out of 100 participants, $85 \%$ of the participants are female, and $15 \%$ male. Conversely, the age group of the respondents varies between 21 years and 55 years (see Table 1). Table 1 also shows that $27 \%$ of the respondents were in between 50 years and 55 years old; hence, it is quite clear that there exists a variation in the age of community health nurses. Table 1 also presents the experience of the community nurses and time spent working in home healthcare in rural Jordan. Nurses averaged moderately lengthy experience in home healthcare (i.e. home health experience of 10-25 years), and relatively long-term employment at their respective agencies.
Table 1: Demographic Data of Community Health Nursing Working in Rural Areas of Jordan $(\mathrm{N}=100)$

\begin{tabular}{|c|c|c|c|}
\hline \multicolumn{2}{|c|}{ Variables } & \multirow[t]{2}{*}{ Frequency } & \multirow[t]{2}{*}{ Percentage } \\
\hline 1. & Gender & & \\
\hline & Male & 15 & 15.0 \\
\hline & Female & 85 & 85.0 \\
\hline \multirow[t]{6}{*}{2.} & Age & & \\
\hline & 21-25 Years & 12 & 12.0 \\
\hline & $26-30$ Years & 23 & 23.0 \\
\hline & $31-40$ Years & 19 & 19.0 \\
\hline & 50-55 Years & 27 & 27.0 \\
\hline & 55 or Retired & 19 & 19.0 \\
\hline \multirow[t]{13}{*}{3.} & $\begin{array}{l}\text { For how } \\
\text { many years }\end{array}$ & & \\
\hline & have you & 26 & 26.0 \\
\hline & worked as a & 32 & 32.0 \\
\hline & community & 18 & 18.0 \\
\hline & $\begin{array}{l}\text { nurse in } \\
\text { home health }\end{array}$ & 24 & 24.0 \\
\hline & in rural & & \\
\hline & areas of & & \\
\hline & Jordan? & & \\
\hline & 5-10 Years & & \\
\hline & $10-25$ Years & & \\
\hline & 25-50 Years & & \\
\hline & Above $\quad 50$ & & \\
\hline & Years & & \\
\hline
\end{tabular}

\section{Survey Responses}

Table 2 presents the responses of the participants against the statement "home visiting programs assist in reaching at-risk population" and "the needs of at-risk pregnant children, mothers and families are being met in your community". The overall analysis of the survey demonstrates that the majority of respondents strongly agreed $(46 \%)$ or agreed $(47 \%)$ with the statement. It indicates that reaching the at-risk population was not a major concern for the nurses as it supported meeting the needs of the community.

Table 2 also presents results of descriptive statistics for nurse respondents on special education and training needs. Nurses reported being exposed to training related to home health on interactions with physicians. A significant percentage of the community nurses (46\%) reported or believed that clinical guidelines, or fixed guidelines introduced and designed for home healthcare improved their efficiency at work. Conversely, quantitative estimates of nurses' contact with their coworkers, physician, and allied caregivers were also observed. They work collaboratively with the social support network to reduce infant mortality. However, these nurses were not known to make joint home visits with them on a continuous basis. They positively ( $29 \%$ agreed) indicated that social support network helped to respond sufficiently, played a role as home health consultants, and respected them as colleagues. Moreover, the community health nurses revealed that infant mortality rates can be controlled easily with the help of home visits by community health nurses. Approximately, $46 \%$ of the participants agreed to the fact that community nurse professionals play a vital role in helping mothers during pregnancy through home visits (Table 2). Furthermore, 33\% of the participants agreed that home support and home visits are considered to be an effective service that aids family (re)unification. 
Table 2: Percent and Frequency of Survey Result conducted from Community Health Nurses ( $N=100)$

\begin{tabular}{|c|c|c|c|c|c|c|c|c|c|c|c|}
\hline \multirow[t]{2}{*}{ No. } & \multirow[t]{2}{*}{ Questions } & \multicolumn{2}{|c|}{ Strongly Disagree } & \multicolumn{2}{|c|}{ Disagree } & \multicolumn{2}{|c|}{ Neutral } & \multicolumn{2}{|c|}{ Agree } & \multicolumn{2}{|c|}{ Strongly Agree } \\
\hline & & Frequency & Percent & Frequency & Percent & Frequency & Percent & Frequency & Percent & Frequency & Percent \\
\hline 1. & $\begin{array}{l}\text { Home visiting } \\
\text { program assist } \\
\text { in reaching at } \\
\text { risk population }\end{array}$ & 1 & 1.0 & 4 & 4.0 & 9 & 9.0 & 46 & 46.0 & 40 & 40.0 \\
\hline 2. & $\begin{array}{l}\text { I have a } \\
\text { supportive } \\
\text { social network } \\
\text { (of physician, } \\
\text { and allied } \\
\text { caregiver) } \\
\text { through which } \\
\text { I can } \\
\text { effectively } \\
\text { work to } \\
\text { improve infant } \\
\text { mortality rate }\end{array}$ & 3 & 3.0 & 6 & 6.0 & 25 & 25.0 & 49 & 49.0 & 17 & 17.0 \\
\hline 3. & $\begin{array}{l}\text { Community } \\
\text { health nurse } \\
\text { plays a vital } \\
\text { role in helping } \\
\text { mothers } \\
\text { during } \\
\text { pregnancy } \\
\text { through home } \\
\text { visits }\end{array}$ & 1 & 1.0 & 4 & 4.0 & 9 & 9.0 & 46 & 46.0 & 40 & 40.0 \\
\hline 4. & $\begin{array}{l}\text { I am } \\
\text { adequately } \\
\text { trained in } \\
\text { home } \\
\text { healthcare to } \\
\text { deliver } \\
\text { optimum care } \\
\text { to mothers } \\
\text { and their } \\
\text { children }\end{array}$ & 3 & 3.0 & 6 & 6.0 & 25 & 25.0 & 49 & 49.0 & 17 & 17.0 \\
\hline 5. & $\begin{array}{l}\text { The needs of } \\
\text { at risk } \\
\text { pregnant } \\
\text { children, } \\
\text { mothers, and } \\
\text { families are } \\
\text { being met in } \\
\text { your } \\
\text { community }\end{array}$ & 5 & 5.0 & 13 & 13.0 & 27 & 27.0 & 47 & 47.0 & 8 & 8.0 \\
\hline 6. & $\begin{array}{l}\text { I receive } \\
\text { continuous } \\
\text { education } \\
\text { related to new } \\
\text { guidelines } \\
\text { introduced } \\
\text { and designed } \\
\text { for home } \\
\text { healthcare }\end{array}$ & 3 & 3.0 & 6 & 6.0 & 16 & 16.0 & 46 & 46.0 & 29 & 29.0 \\
\hline 7. & $\begin{array}{l}\text { In home } \\
\text { support and } \\
\text { home, visits is } \\
\text { considered to } \\
\text { be an effective } \\
\text { service that } \\
\text { you feel aids } \\
\text { family reunify }\end{array}$ & 12 & 12.0 & 19 & 19.0 & 28 & 28.0 & 33 & 33.0 & 8 & 8.0 \\
\hline
\end{tabular}


The correlation matrix shown in Table 3 illustrates the results of the correlation test, performed to determine the type of correlation between nursing home visits and infant mortality rate. A Pearson correlation value of 0.751 indicates that a positive correlation exists between the two selected variables of nursing home visits and infant mortality rates.

Moreover, the correlation between nursing home visits and infant mortality rate is noted to be significant, as the value of significance 0.012 , observed between the two variables, is less than 0.05 . From the results of the correlation test, it can be deduced that a positive and significant relation exists between the increase in nursing home visits and a decrease in the rate of infant mortality. Hence, infant home visitation by community health nurses is a promising means to reduce the mortality rates among infants living in highly disadvantaged settings.

Table 3: Results of Pearson Correlation Test

\begin{tabular}{|c|c|c|c|}
\hline & & $\begin{array}{c}\text { Increased Nursing } \\
\text { home visits }\end{array}$ & $\begin{array}{c}\text { Decreased infant } \\
\text { mortality rate }\end{array}$ \\
\hline \multirow{3}{*}{$\begin{array}{l}\text { Increased } \\
\text { Nursing home } \\
\text { visits }\end{array}$} & $\begin{array}{l}\text { Pearson } \\
\text { Correlation }\end{array}$ & 1 & $.751^{*}$ \\
\hline & Sig. (2-tailed) & & .012 \\
\hline & $\mathbf{N}$ & 100 & 100 \\
\hline \multirow{3}{*}{$\begin{array}{c}\text { Decreased } \\
\text { infant } \\
\text { mortality rate }\end{array}$} & $\begin{array}{c}\text { Pearson } \\
\text { Correlation }\end{array}$ & $.751^{*}$ & 1 \\
\hline & Sig. (2-tailed) & .012 & \\
\hline & $\mathbf{N}$ & 100 & 100 \\
\hline
\end{tabular}

\section{DISCUSSION}

This cross-sectional survey offered essential information on the degree to which the home visits by community health nurses are important and effective in influencing care and health of an infant. The variables examined in the study included how visits by community health nurses to support and promote evidence-based infant care practices, along with emphasizing reducing some of the most widespread and damaging concerns faced by families and low income individuals living in rural areas of Jordan. Lower rates of mortality found among children, whom community nurses have visited considerably reflects that nurses' are effectively supporting mothers and protecting their children. The correlation analysis results indicate that a significant relationship exists between the increase in nurse home visits and improvements in the rates of infant mortality. The results of our study are consistent with the findings of Hockenberry and Wilson, indicating that the home visits by community health nurses are helpful for the mother and reduce the risk of acute complications and improve the child's outcome(33). The requirement for strengthened participation of community nurses in home visits has been the impetus for scheming different strategies that can assist to improve client-provider association. Interventions have embraced suppleness in the core services in order to better meet individual expectations and needs of clients along with offering access to subsidiary services for instance, support group sessions (14, $34,35)$. Limited attention has been given to it; however devoted to family engagement strategies that consider exclusive requirements and community challenges.

In other countries, through similar channels of influence, community violence is known to deter retention in home visits. Home visits acceptance and community-level support can assist to diminish individual ambivalence related to strengthening retention and service value. Conversely, in Jordan, people welcome the nurses who are doing home visits, especially in rural areas. Different community-based strategies are utilized in "Harlem Children's Zone, Inc." within the Harlem community, whereas broad reach triggers a positive shift in academic attainment of a child (36). Various community-based interventions assist to improve the outcomes of infants by means of support groups, home visiting, and community mobilization (37). This also aids to improve the infant mortality rates.

According to Malkawi, the infant mortality rates in Jordan have improved, declining from 48 deaths per 100,000 births in 1990 , to 19 by 2009(38). Taha et al. suggested that enhancing the knowledge of nurses can only help to improve the rates of infant mortality(39).

Hence, in the past year, the conditions in Jordan have improved due to home visits. The utilization of community health nurses as part of the home- visiting team is effectual, with the team of nurses fulfilling the requirements of families at huge risk of poor outcomes for their infants. This strategy is of national interest due to its potential to attain the required outcomes in a costeffective way.

This study also supported the findings, where community health nurse were the preferred choice of home visitors due to their formal training with females, as well as child health, along with their competence in managing complicated clinical conditions often demonstrated by "at-risk families".

Based on these findings, a potential strategy needs to be formed to improve the capabilities of community health nurses to competently address family members' and mothers' concerns related to delivery, labor, and pregnancy complications, as well as physical infant health are considered to offer nurses with persuasive power in front of a family member's eyes and increases the credibility of nurses (40). Additionally, by means of their capability to teach family members and mothers to examine emerging health concerns and to utilize the system of healthcare, nurses are known to increasingly use their capabilities in treating infant issues and early detect such concerns which consequently reduce mortality rates of infants $(41,42)$.

The strength of this study was to incorporate effective research design supporting the knowledge about the effectiveness of home visits by community health nurses. This study entails important insights regarding the awareness of community nurse home visits.

\section{Acknowledgements}

M.K. would like to extend sincere gratitude and appreciation to all the people who contributed for the accomplishment of this task. The research process required higher level of commitment and dedicated efforts, and the facilitators were a source of motivation and enrichment with their invaluable contribution in this study.

\section{Conflict of interest}

No conflict of interest was declared by the authors

\section{REFERENCES}

1. Avellar SA, Supplee LH. Effectiveness of home visiting in improving child health and reducing child maltreatment. Pediatrics 2013; 132: 90-9.

2. Weiss HB. Home visits: Necessary but not sufficient. Future Child 1993; 3: 113-28.

3. Gomby DS. Home visitation in 2005: Outcomes for children and parents (dissertation). Washington, DC: Committee on Economic Development. 2005.

4. Astuto J, Allen L. Home visitation and young children: An approach worth investing in? Society for Research in Child Development. Social Policy Report 2009; 23: 3-22.

5. Adirim T, Supplee L. Overview of the federal home visiting program. Pediatrics 2013; 132: 59-64.

6. Sweet MA, Appelbaum MI. Is home visiting an effective strategy? A meta-analytic review of home visiting programs for families with young children. Child Dev 2004; 75 1435-56.

7. Shonkoff JP, Garner AS, Siegel BS, Dobbins MI, Earls MF, McGuinn L et al. The lifelon effects of early childhood adversity and toxic stress. Pediatrics 2012; 129: e232-e46.

8. Luby J, Belden A, Botteron K, Marrus N, Harms MP, Babb C et al. The effects of poverty on childhood brain development: The mediating effect of caregiving and stressful life events. JAMA Pediatrics 2013; 167: 1135-1142. Doi: 10.1001/jamapediatrics.2013.3139.

9. Olds DL, Kitzman H, Cole R, Robinson J, Sidora K, Luckey DW et al. Effects of nurse home-visiting on maternal life course and child development: Age 6 follow-up results of a randomized trial. Pediatrics 2004; 114: 1550-9.

10. Olds DL, Kitzman H, Knudtson MD, Anson E, Smith JA, Cole R. Effect of home visiting by nurses on maternal and child mortality: Results of a 2-decade follow-up of a randomized clinical trial. JAMA Pediatrics 2014; 168: 800-6.

11. DuMont K, Kirkland K, Mitchell-Herzfeld S, Ehrhard-Dietzel S, Rodriguez ML, Lee E et al. A randomized trial of Healthy Families New York (HFNY): Does home visiting prevent child maltreatment. 2010. Available from: URL https://www. ncjrs. gov/pdffiles1/nij/grants/232945. pdf.

12. Caldera D, Burrell L, Rodriguez K, Crowne SS, Rohde C, Duggan A. Impact of statewide home visiting program on parenting and on child health and development Child Abuse \& Neglect 2007; 31: 829-52.

13. Duggan A, McFarlane E, Fuddy L, Burrell L, Higman SM, Windham A et al. (2004). Randomized trial of a statewide home visiting program: Impact in preventing child abuse and neglect. Child Abuse \& Neglect 2004; 28: 597-622.

14. O’Brien RA, Moritz P, Luckey DW, McClatchey MW, Ingoldsby EM, Olds DL. Mixed methods analysis of participant attrition in the nurse-family partnership. Prevention Science 2012; 13: 219-28.

15. Duggan A, Caldera D, Rodriguez K, Burrell L, Rohde C, Crowne SS. Impact of a statewide home visiting program to prevent child abuse. Child Abuse \& Neglect 2007; 31: 801-27.

16. Holland ML, Xia Y, Kitzman HJ, Dozier AM, Olds DL. Patterns of visit attendance in the nurse-family partnership program. Am J Public Health 2014; 104: 58-65. 
17. Goyal NK, Hall ES, Meinzen-Derr JK, Kahn RS, Short JA, Van Ginkel JB et al. Dosage effect of prenatal home visiting on pregnancy outcomes in at-risk, first-time mothers. Pediatrics 2013; 132: 118-25

18. Nievar MA, Van Egeren LA, Pollard S. A meta-analysis of home visiting programs: Moderators of improvements in maternal behavior. Infant Ment Health J 2010; 31: 499-520.

19. Khoury SA, Mas' ad DF. Causes of infant mortality in Jordan. Saudi Medical Journal 2002; 23: 432-5

20. Dababneh $F$, Nichols EK, Asad $M$, Haddad $Y$, Notzon $F$, Anderson $R$. Improving mortality data in Jordan: a 10 year review. Bulletin of the World Health Organization 2014; 93: 727-31.

21. Hundt GL, Alzaroo S, Hasna F, Alsmeiran M. The provision of accessible, acceptable health care in rural remote areas and the right to health: Bedouin in the North East region of Jordan. Social Science \& Medicine 2012; 74: 36-43.

22. Nagy E. The newborn infant: A missing stage in developmental psychology. Infant and Child Development 2011; 20: 3-19.

23. Russell S, Drennan V. Mothers' views of the health visiting service in the UK: a webbased survey. Community Practitioner 2007; 80: 22-26. The development and validation of tools to measure the parent/health visitor relationship (PhD thesis). King's College London. 2013.

25. Plews $\mathrm{C}$, Bryar R, Closs J. Clients' perceptions of support received from health visitors during home visits. Journal of Clinical Nursing 2005; 14: 789-97.

26. Jack SM, DiCenso A, Lohfeld L. A theory of maternal engagement with public health nurses and family visitors. J Adv Nurs 2005; 49: 182-90.

27. Cowley S, Whittaker K, Malone M, Donetto S, Grigulis A, Maben J. Why health visiting? Examining the potential public health benefits from health visiting practice within a universal service: a narrative review of the literature. Int J Nurs Stud 2015; 52: $465-80$.

28. Plews $C$. A consumer perspective on advice/information received from the health visitor during a home visit. Clinical Effectiveness in Nursing 1998; 2: 122-30.

29. McIntosh J, Shute J. The process of health visiting and its contribution to parental support in the Starting Well demonstration project. Health \& Social Care in the Community 2007; 15 : 77-85.
24. Bidmead C. Health visitor/parent relationships: a qualitative analysis. Excerpt from

Community health nurse

30. Department of Health. Improving outcomes and supporting transparency. Part 1A: public health outcomes framework for England, 2013-2016. Department of Health 2014; London

31. Donetto $S$, Maben J. These places are like a godsend': a qualitative analysis of parents experiences of health visiting outside the home and of children's centers services. Health Expect 2015; 18: 2559-69.

32. Creswell JW. Research design: Qualitative, quantitative, and mixed methods approach. Sage Publications; 2013.

33. Hockenberry MJ, Wilson D. Wong's nursing Care of Infants and Children Multimedia Enhanced Version. Elsevier Health Sciences 2013.

34. Ingoldsby EM, Baca P, McClatchey MW, Luckey DW, Ramsey MO, Loch JM et al. Quasiexperimental pilot study of intervention to increase participant retention and completed home visits in the nurse-family partnership. Prevention Science 2013; 14: 525-34.

35. Constantino JN, Hashemi N, Solis E, Alon T, Haley S, McClure S et al. Supplementation of urban home visitation with a series of group meetings for parents and infants: Results of a Breal-world randomized, controlled trial. Child Abuse \& Neglect 2001; 25 : 1571-81.

36. Dobbie W, Fryer RG Jr. Are high-quality schools enough to increase achievement among the poor? Evidence from the Harlem children's zone. American Economic Journal: Applied Economics 2011; 3: 158-87.

37. Lassi ZS, Haider BA, Bhutta ZA. Community-based intervention packages for reducing maternal and neonatal morbidity and mortality and improving neonatal outcomes. Cochrane Database Syst Rev 2010; 11. Doi: 10.1002/14651858.CD007754.

38. Malkawi K. Reducing infant, maternal mortality key to meeting millennium goals in Jordan. $2012 . \quad$ Available from: URL http://vista.sahafi.jo/art.php?id=1bb5cea1c79d085d154bf33804c99ffbec6205c1.

39. Taha $\mathrm{H}$, Nyström L, Al-Qutob R, Berggren V, Esmaily H, Wahlström R. Home visits to improve breast health knowledge and screening practices in a less privileged area in Jordan. BMC Public Health 2014; 14: 428. Doi: 10.1186/1471-2458-14-428.

40. Gallup Organization. Nurses remain at top of honesty and ethics poll; 2000.

41. Marston C, Renedo A, McGowan CR, Portela A. Effects of community participation on improving uptake of skilled care for maternal and newborn health: A systematic review.PLoS ONE 2013; 8: e55012. Doi: http://dx.doi.org/10.1371/journal.pone.0055012

42. Bomar PJ. Community-based participatory nursing research: A culturally focused case study. Jpn J Nurs Sci 2010; 7: 1-8. Doi: 10.1111/j.1742-7924.2010.00145.x.

\section{Please select the number which best describes your opinion}

1 Strongly disagree. 2 Disagree. 3 Neutral. 4 Agree. 5 Strongly agree

\section{Demographic Questionnaire}

\begin{tabular}{ll}
\hline 1. Gender & Male \\
& Females \\
& $21-25$ years \\
& $26-30$ years \\
& $31-40$ years \\
2. Age & $50-55$ years \\
& 55 or Retired \\
3. For how many years have you & $5-10$ years \\
worked as a community nurse in & $10-25$ years \\
home health in rural areas of & $25-50$ years \\
Jordan? & Above 50 years \\
\hline
\end{tabular}

The following statements are to know your opinion regarding Statements

$\begin{array}{lllll}1 & 2 & 3 & 4 & 5\end{array}$

$1 \quad$ Home visiting programs assist in reaching at risk population

2 I have a supportive social network (of physician, and allied caregiver) through which I can effectively work to improve infant mortality rate

3 Community health nurse plays a vital role in helping mothers during pregnancy through home visits

$4 \quad$ I am adequately trained in home healthcare to deliver optimum care to mothers and their children

5 The needs of at-risk pregnant children, mothers and families are being met in your community

$6 \quad$ I receive continuous education related to new guidelines introduced and designed for home healthcare

7 In home support and home, visits is considered to be an effective service that you feel aids families reunify 